\title{
PENGENALAN STRATEGI AVP BAGI PELAKU USAHA MIKRO PADA KOMUNITAS PEMUDA DESA GELAM JAYA KABUPATEN TANGERANG
}

\author{
Sonny Santosa*1, Rini Novianti² \\ 1,2Universitas Buddhi Dharma \\ ${ }^{1}$ Program Studi Manajemen, Fakultas Bisnis \\ 2Program Studi Akuntansi, Fakultas Bisnis \\ *e-mail: snnsantosa@gmail.com ${ }^{1}$ rini.novianti@ubd.ac.id ${ }^{2}$
}

\begin{abstract}
Pandemic crisis experienced by almost all countries even Indonesia has made such a rapid change in the joints of human life. This change is what causes the domino effect, both positive and negative. This domino effect is also engulfing the scope of economic business, in other words the faster the spread of the covid-19 virus, in other words, more and more businesses will be disrupted so that it could threaten the global economy of a Country. In that global threat, businesses must continue to survive, at least striving to increase sales as much as possible to keep the business running. AVP (Avaibility, Visibility, and Promotion) strategy is considered as the basis that must be known and owned by each business in order to maintain its business or business. This community service activity is aimed specifically at the youth community of Gelam Jaya Tangerang Regency by using online methods in the delivery of this socialization, the result of this community service shows the interest of members of the Gelam Jaya youth community to develop the power of efforts to maintain back so that their businesses continue to run at least in the pattern of maintaining the type of business / business that they previously run.
\end{abstract}

Keywords: AVP Strategy

\begin{abstract}
Abstrak
Krisis Pandemi yang dialami oleh hampir semua Negara bahkan Indonesia sekalipun telah membuat perubahan yang begitu cepat pada sendi kehidupan manusia. Perubahan inilah yang menimbulkan efek domino, baik yang bersifat positif maupun negative. efek domino inipun yang melanda cakupan bisnis perekonomian, dengan kata lain semakin cepat penyebaran virus covid-19 maka dengan kata lain akan semakin banyak pula bisnis yang terganggu sehingga bisa saja mengancam perekonomian secara global suatu Negara. Dalam ancaman global itulah, para pelaku bisnis harus terus bertahan, setidaknya berjuang untuk meningkatkan penjualan sebisa mungkin untuk dilakukan agar membuat bisnis tetap berjalan. Strategi AVP (Avaibility, Visibility, dan Promotion) dianggap sebagai dasar yang harus diketahui dan dimiliki oleh tiap pelaku usaha agar dapat mempertahankan usaha atau bisnisnya. Kegiatan pengabdian masyarakat ini ditujukan khusus kepada komunitas pemuda Gelam Jaya Kabupaten Tangerang dengan menggunakan metode daring dalam penyampaian sosialisasi ini, hasil dari pengabdian masyarakat ini menunjukkan adanya ketertarikan dari para anggota komunitas pemuda Gelam Jaya untuk menumbuh kembangkan daya upaya mempertahankan kembali agar bisnis yang mereka miliki tetap berjalan setidaknya dalam pola mempertahankan jenis usaha/bisnis yang sebelumnya mereka jalankan.
\end{abstract}

Kata kunci: Strategi AVP 


\section{PENDAHULUAN}

Penyelanggaran pemerintahan yang baik merupakan harapan bagi semua masyarakat. Hal tersebut merupakan perwujudan dari sebuah proses pembangunan baik bagi pemerintah maupun masyarakat itu sendiri. Terwujudnya hasil dari pemerintahan yang baik salah satunya merupakan perwujudan dari proses penyerapan aspirasi yang ada di masyarakat. Melalui hasil dari pelaksanaan musyawarah yang ada di desa, masyarakat bisa langsung menyampaikan gagasan, usulan, saran dan kritik yang baik sehingga dapat secara bersama-sama dengan pihak pemerintah membangun Pemerintahan yang baik, sesuai dengan cita-cita bangsa dan Negara (Roza \& S, 2018).

Mengacu pada informasi yang didapat dari laporan e-economy SEA 2019 ("SEA_Internet_Economy_Report_2019," 2019), Secara garis besar memuat sebuah informasi yang cukup membuat mata kita terbuka lebar bahwa meskipun ditengah masa pandemic covid-19, Indonesia justru menjadi salah satu Negara yang memiliki nilai perekonomian secara digital terbesar untuk kawasan Asia Tenggara, hal ini dibuktikan dengan mulai maraknya transaksi secara daring atau yang sering kita kenal sebagai e-commerce. Tentu saja informasi yang didapat ini bisa dijadikan sebagai dasar kekuatan Indonesia untuk bangkit mengejar ketertinggalan yang ada selama ini, peluang berwirausaha secara daring yang selama ini menjadi bagian dari cerug pasar kini mulai terlihat dan begitu menjanjikan.

Menjadikan momentum pandemi sebagai kebangkitan baru Indonesia dalam melakukan sebuah lompatan besar merupakan hal terpenting yang disampaikan oleh Presiden RI pada saat Sidang Tahunan MPR RI (Humas, 2020) oleh karena itu, diperlukan adanya strategi pemasaran yang tepat guna menjadi elemen krusial dalam menentukan eksistensi keberlangsungan sebuah usaha atau bisnis. Selain itu, kita kembali diingatkan mengenai peran penting dan kontribusi signifikan strategi pemasaran bagi survivabilitas dan supremasi pemasaran itu sendiri. Pandemi yang tidak hanya dialami oleh Indonesia, tentu akan mendorong terciptanya sebuah dinamika lingkungan bisnis yang menghadirkan berbagai perspektif, ancangan dan lingkup strategi pemasaran berdasarkan posisi kompetitif (Tjiptono, 2015).

Strategi AVP (avaibility, visibility, \& promotion) merupakan langkah awal dari sebuah bagian dari dinamika strategi pemasaran dalam berbagai konteks, melalui strategi AVP kita kembali dikenalkan pada sebuah dinamika strategi pemasaran, baik itu dalam lingkup strategi kepuasan pelanggan maupun menelaah strategi pasar yang biasanya memuat cakupan besar seperti pasar, geografis pasar dan market entry hingga komitmen pasar dan market dilution strategy. Tentu saja sebelum kita membicarakan aspek lain dalam sebuah strategi pemasaran seperti strategi branding, produk, penetapan harga, distribusi, dan komunikasi pemasaran yang terintegrasi, maka pelaku usaha akan melalui tahap pertama diawal dulu yaitu strategi AVP, dengan kita mengenal strategi AVP inilah maka para pelaku usaha dapat membuka elemen bauran pemasaran (marketing mix) dalam sebuah praktik dari unsur strategik dan taktikal.

Dalam mempertahankan laju sebuah usaha atau bisnis, maka para pelaku usaha harus mengetahui Strategi AVP yang merupakan elemen pokok dalam pemikiran dan praktik pemasaran modern, tidak hanya mengenai strategi mempertahankan sebuah usaha atau bisnis tetapi juga dengan mengenal strategi AVP ini, para pelaku usaha mendapat nilai lebih dalam memenangkan persaingan baik menciptakan ataupun mempertahankan pelanggan yang sudah ada, kesemua hal ini terletak pada kemampuan bagaimana para pelaku usaha mikro memahami perilaku konsumen secara komprehensif, kemudian memanfaatkan 
pemahaman tersebut untuk merancang dan mengkomunikasikan serta menyampaikan program pemasaran secara lebih efektif dibandingkan para pesaing, dengan kata lain, kita sebagai pelaku usaha harus mampu bersikap dinamis (Widiana, 2010).

Berdasarkan data (Statistik, 2020) diketahui bahwa Indeks Pembangunan Manusia khusus di wilayah provinsi Banten menunjukkan angka 71,92 hal ini menunjukkan Kabupaten Tangerang bisa dijadikan sebagai bagian indicator dalam mengukur keberhasilan dalam upaya membangun kualitas hidup masyarakat/penduduk di Provinsi Banten.

Tabel 1. Indeks Pembangunan Manusia Di Provinsi Banten Tahun 2020

\begin{tabular}{|c|c|c|c|}
\hline \multirow{2}{*}{ Kabupaten/Kota } & \multicolumn{3}{|c|}{$\begin{array}{c}\text { Indeks Pembangunan Manusia (IPM) Menurut } \\
\text { Kabupaten/Kota di Provinsi Banten }\end{array}$} \\
\cline { 2 - 4 } & 2018 & 2019 & 2020 \\
\hline Kab Pandeglang & 64,34 & 64,91 & 65,00 \\
\hline Kab Lebak & 63,37 & 63,88 & 63,91 \\
\hline Kab Tangerang & 71,59 & 71,93 & 71,92 \\
\hline Kab Serang & 65,93 & 66,38 & 66,70 \\
\hline Kota Tangerang & 77,92 & 78,43 & 78,25 \\
\hline Kota Cilegon & 72,65 & 73,01 & 73,05 \\
\hline Kota Serang & 71,68 & 72,10 & 72,16 \\
\hline Kota Tangerang Selatan & 81,17 & 81,48 & 81,36 \\
\hline Provinsi Banten & 71,95 & 72,44 & 72,45 \\
\hline
\end{tabular}

\section{Catatan : IPM 2013, Angka Sementara}

Source Url: https://banten.bps.go.id/indicator/26/73/1/indeks-pembangunanmanusia-ipm-menurut-kabupaten-kota-di-provinsi-banten.html

Access Time: March 01, 2021, 10:26 am

Indeks pembangunan manusia ini bisa saja kita jadikan acuan dalam menentukan peringkat atau level pembangunan suatu wilayah atau Negara. Standar hidup layak dijadikan sebagai salah satu indicator dalam menyusun indeks pembangunan manusia karena indeks pembangunan manusia sesungguhnya memiliki makna yang luas, ide dasar dari indeks pembangunan manusia ini adalah menciptakan pertumbuhan positif dalam bidang ekonomi, sosial, politik, budaya dan lingkungan serta perubahan dalam kesejahteraan manusia dalam sebuah wilayah/Negara.

Kelurahan (desa) Gelam jaya merupakan salah satu desa yang berada dalam wilayah administrasi Gelam Jaya Kec. Pasar Kemis Kab. Tangerang. Kel/desa Gelam Jaya merupakan satu-satunya desa yang berada paling dekat dengan perbatasan dari beberapa wilayah yang termasuk didalam wilayah Kota Tangerang, oleh karena itu, Kel/Desa Gelam Jaya ini sedikit banyak mendukung Kabupaten Tangerang untuk memiliki angka capaian indeks pembangunan manusia yang angkanya terbesar keempat se-provinsi Banten. Konsep pembangunan manusia ini lebih memfokuskan kepada perluasan pilihan masyarakat dengan bebas dan bermartabat, sehingga dengan demikian indeks pembangunan manusia ini melihat secara bersamaan semua isu dalam masyarakat (Statistik, 2019). 
Desa Gelam Jaya merupakan hasil dari pemekaran Kelurahan Kuta Jaya Kecamatan Pasar Kemis Kabupaten Tangerang, sejak terpisah dari Kelurahan Kuta Jaya, Desa Gelam Jaya telah beberapa kali mengalami pergantian kepemimpinan sebagai Kepala Desa Gelam Jaya, pentingnya memahami kondisi desa untuk mengetahui keterkaitan perencanaan dengan muatan pendukung dan permasalahan yang ada, memberikan arti penting keputusan pembangunan sebagai langkah mendayagunakan dan penyelesaian masalah di masyarakat. Desa gelam jaya merupakan salah satu dari 5 desa di wilayah Kecamatan Psar Kemis, yang terletak $4 \mathrm{Km}$ dari Kecamatan Pasar Kemis. Desa Gelam jaya mempunyai luas wilayah seluas 294 hektar dengan masing-masing batas yang telah ditentukan (Pelaksanaan Kewajiban, Aribowo, \& Usman, 2018)

Oleh karena itu, untuk meningkatkan angka indeks pembangunan manusia di Kabupaten Tangerang, khususnya di kel./desa gelam jaya maka dianggap perlu adanya sosialiasi pengenalan strategi AVP bagi pelaku usaha mikro pada komunitas pemuda gelam jaya Kabupaten Tangerang, agar dapat menjadi sebuah modal awal bagi pelaku usaha mikro (khususnya) para pemuda sebagai tonggak dalam era millennial untuk menghadapi segala kemungkinan dalam menjalankan/membantu usaha mikro baik yang sudah maupun baru akan memulai usaha mikro untuk meningkatkan taraf hidup individu ataupun secara menyeluruh.

\section{METODE}

Metode pelaksanaan kegiatan pengabdian ini adalah sosialisasi pengenalan strategi AVP melalui daring (Microsoft Teams) selama 2 hari di jam 19.30-21.30, pengenalan konsep AVP (avaibility, visibility, dan promotion) ini sangat penting untuk menyelaraskan tujuan pemasar, kompetensi dan kapasitas, serta pilihan produk yang ditawarkan dengan tujuan, prioritas pembelian dan preferensi konsumen, sehingga transaksi, relasi dan kepuasan dapat terwujud. Seperti yang kita ketahui bahwa setiap pemasar memiliki berbagai kombinasi tujuan (diantaranya, survival, finansial, sosial dan seterusnya), yang ingin diwujudkan melalui penawaran produk. Namun, tidak semua kemungkinan alternatif produk mampu dihasilkan, karena amat tergantung pada kompetensi dan kapasitas sumber daya (modal, sumber daya manusia, bahan mentah, waktu, kewirausahaan dan seterusnya) yang dimiliki. Sementara itu, setiap konsumen memiliki bermacam-macam tujuan (mencari solusi atas permasalahan yang dihadapi, memburu manfaat ekonomis dan lain-lain) yang ingin dipenuhi lewat akses, kepemilikan, dan konsumsi barang atau jasa tertentu.

Adapun tahapan yang dilalui untuk melaksanakan pengabdian masyarakat ini adalah sebagai berikut :

\section{Tahap Perencanaan}

Dalam tahap ini, tim fasilitator, menyusun formulir pendaftaran kegiatan pengenalan strategi AVP pada komunitas pemuda Gelam Jaya dengan cara menyebarkan link pendaftaran https://forms.gle/56W8K4FFxgAm7hhv7 .

\section{Tahap Pendataan}

Dalam tahap ini, tim fasilitator, melakukan pendataan ulang terjadap formulir kepesertaan yang telah diisi, dalam pendataan ini, tim fasilitator dapat melihat adanya 42 Peserta yang mendaftar untuk di Hari Pertama, dan 35 Peserta yang mendaftar untuk di Hari Kedua (mayoritas masih didominasi oleh peserta yang mengikuti pengenalan ini secara lengkap 2 hari).

3. Tahap Pelaksanaan 
Proses pengenalan strategi AVP yang dilakukan melalui daring ini, dilakukan selama 2 hari, Tanggal 19-20 Maret 2021 Jam 19.30-21.30, jam pelaksanaan memang dilaksanakan di jam 19.30 dengan harapan mampu menjaring banyak pemuda yang akan mengikuti kegiatan pengenalan strategi AVP ini agar sama-sama mempunyai modal awal untuk menjalani kegiatan usaha atau bisnisnya masing-masing. Adapun tanggal pelaksanaan dan durasi pelaksanaan kegiatan pengenalan strategi AVP pada pelaku usaha dapat dilihat pada tabel 2 dibawah ini :

Tabel 2. Agenda Pelaksanaan Kegiatan Pengenalan Strategi AVP

\begin{tabular}{|c|c|c|c|}
\hline No & Pertemuan $\mathrm{Ke}$ & Pembahasan & Durasi Pelaksanaan \\
\hline 1 & $\begin{array}{l}1 \text { (Jumat, } 19 \text { Maret } \\
\text { 2021, Jam 19.30- } \\
21.30 \text { ) }\end{array}$ & $\begin{array}{l}\text { Strategi Kepuasan Pelanggan } \\
\text { a. Pendahuluan (Pra } \\
\text { Test) } \\
\text { b. Bagaimana } \\
\text { Usaha/Bisnis Di Masa } \\
\text { Pandemi }\end{array}$ & $2 \mathrm{Jam}$ \\
\hline 2 & $\begin{array}{l}2 \text { (Sabtu, } 20 \text { Maret } \\
\text { 2021, Jam 19.30- } \\
21.30 \text { ) }\end{array}$ & $\begin{array}{ll}\text { a. } & \text { Bukan Sekedar Puas } \\
\text { b. } & \begin{array}{l}\text { Strategi AVP } \\
\text { (Avaibility, Visibility } \\
\text { dan Promotion) }\end{array} \\
\text { c. } & \text { Post Test }\end{array}$ & $2 \mathrm{Jam}$ \\
\hline \multicolumn{3}{|r|}{ Total Jam Kegiatan } & $4 \mathrm{Jam}$ \\
\hline
\end{tabular}

\section{Tahap Evaluasi}

Hasil dari kegiatan pengenalan Strategi AVP yang berbalut dalam jenis kegiatan pengabdian kepada masyarakat ini pada akhirnya memerlukan sebuah evaluasi. Hasil pengabdian ini dapat diukur dengan 2 cara, yaitu :

a. Angket

dalam kegiatan ini, para peserta diberikan angket dan post test untuk melihat kendala yang dialami oleh para pelaku usaha serta untuk melihat ketertarikan para pelaku usaha untuk menjalankan sebuah usaha. https://forms.gle/xq4nCjenCKXdkFnS9

b. Keberlanjutan

Dalam tahap ini, tim fasilitator memberikan pengenalan lebih jauh terhadap konsep pemasaran yang nantinya akan sangat berguna dalam membekali para peserta untuk menumbuhkembangkan jiwa wirausaha demi meningkatkan taraf hidup masyarakat. Selain itu evaluasi juga dilakukan dengan cara Tanya jawab secara langsung terhadap materi atau topic pembahasan yang telah dijelaskan selama proses kegiatan pengenalan strategi AVP ini dilakukan. 


\section{HASIL DAN PEMBAHASAN}

Kegiatan Pengabdian kepada masyarakat ini dilaksanakan selama 2 hari dengan 2 jam/pertemuan sehingga total kegiatan ini adalah 4 jam. Dari kegiatan ini diharapkan dapat menumbuhkembangkan semangat para pemuda yang baru akan memulai usaha atau membantu usaha keluarga. Kegiatan pengenalan strategi AVP ini terbukti memiliki nilai lebih dalam memulai sebuah usaha, selain itu nampak dari tanya jawab peserta dan tim fasilitator mampu memberikan suatu nilai tambah bagi masyarakat, baik dalam kegiatan ekonomi, kebijakan, dan perubahan perilaku (sosial). Hal ini terlihat dari hasil post test yang diberikan sebelum dan setelah selesai kegiatan serta dari sesi Tanya jawab kegiatan pengenalan strategi AVP ini.

\section{Pertemuan ke-1}

Pada pertemuan ini dilakukan pemaparan terhadap materi "bagaimana memulai atau mempertahankan usaha/bisnis di masa pandemic.?" Proses pemaparan dengan cara brainstorming dimana tim fasilitator mengedapankan pada responsive dari para peserta untuk mampu memberikan tanggapan terhadap sebuah issue/fenomena terkait perkembangan usaha/bisnis dimasa pandemic.

\section{Bagaimana Bisnis Pasca Pandemi}
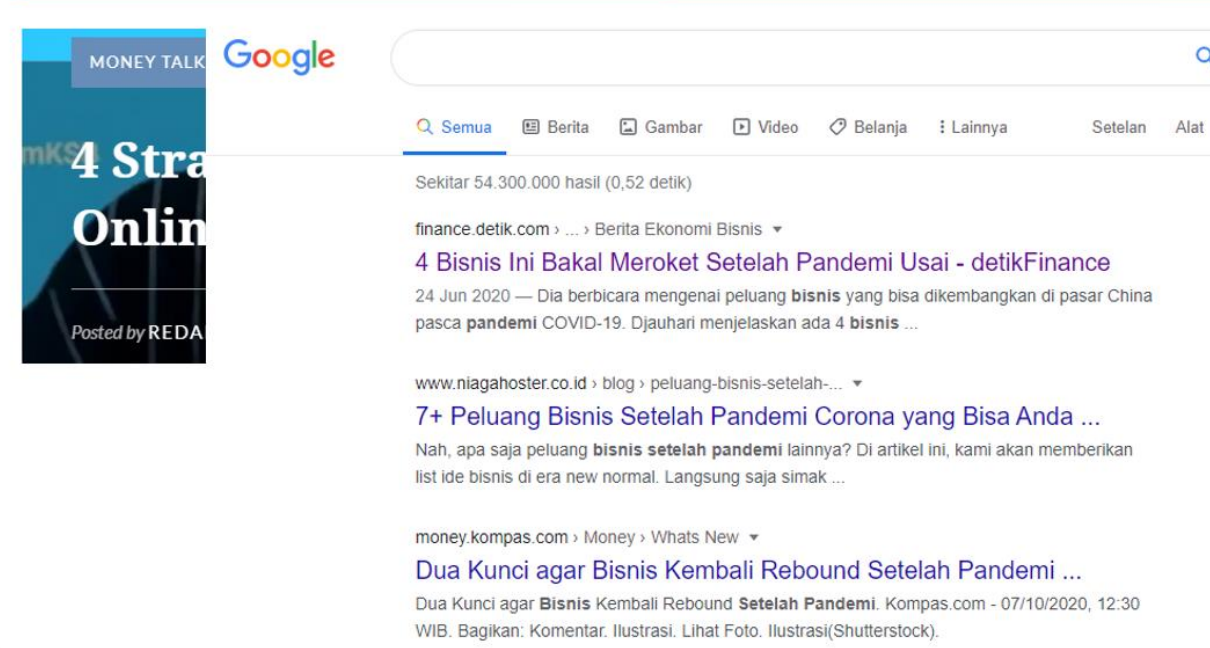

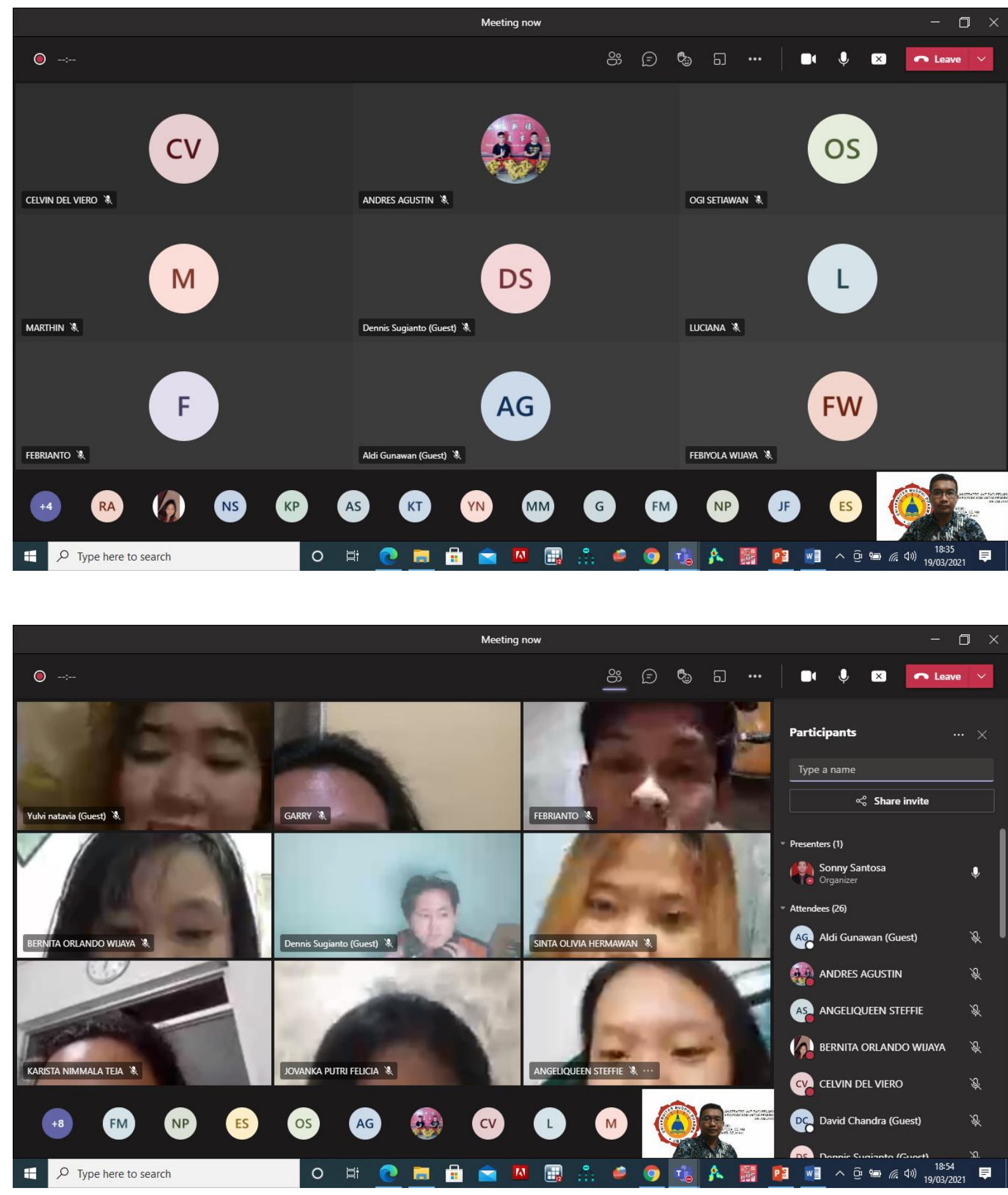

Gambar 1. Pertemuan Ke 1 Pada Tanggal 19 Maret 2021 Jam 19.30 Melalui Teams. 
Proses pemaparan materi di hari ke-1 ini memakan waktu 2 jam, dengan pembahasan materi seputar :

a. Bagaimana bisnis pasca pandemic.

b. Siklus kehidupan produk

\section{Pertemuan ke-2}

Pada pertemuan kedua, dilakukan lanjutan pemaparan inti mengenai Pengenalan Strategi AVP (avaibility, visibility dan promotion) dalam mempertahankan usaha/bisnis di masa pandemic seperti saat ini.

Proses pemaparan materi di hari ke-2 ini memakan waktu 2 jam, dengan pembahasan materi inti yaitu pengenalan strategi AVP bagi pelaku usaha mikro. Dalam Tanya jawab materi AVP, terlihat banyak antusiasme para peserta untuk bertanya, diantaranya tim fasilitator merangkum sebagai berikut :

Tabel 3. Daftar Pertanyaan Dari Peserta

\begin{tabular}{|l|l|l|l|}
\hline No & \multicolumn{1}{|c|}{ Nama Penanya } & \multicolumn{1}{|c|}{$\begin{array}{c}\text { Jenis Usaha/Nama } \\
\text { Produk }\end{array}$} & \multicolumn{1}{|c|}{ Pertanyaan } \\
\hline 1 & Tonih & $\begin{array}{l}\text { Susu Kacang } \\
\text { Soechang_98 }\end{array}$ & $\begin{array}{l}\text { Bagaimana kita dapat mengembangkan } \\
\text { bisnis secara serius sebagai seorang } \\
\text { pemula.? }\end{array}$ \\
\hline 2 & Celvin & $\begin{array}{l}\text { Salad Sayur: } \\
\text { MAMAkE }\end{array}$ & $\begin{array}{l}\text { Apa sih bedanya bisnis dengan } \\
\text { berdagang.? }\end{array}$ \\
\hline 3 & Aldy & $\begin{array}{l}\text { Laundry: } \\
\text { Kang_Laundry }\end{array}$ & $\begin{array}{l}\text { Apa hubungannya antara strategi AVP } \\
\text { dengan platform bisnis yang sudah } \\
\text { banyak tersedia saat ini.? }\end{array}$ \\
\hline 5 & Adrian & $\begin{array}{l}\text { Laundry: } \\
\text { Be2rSIH }\end{array}$ & $\begin{array}{l}\text { Sejauh mana strategi AVP ini bisa } \\
\text { menempatkan produk kita menjadi } \\
\text { pilinan utama bagi konsumen.? }\end{array}$ \\
\hline 6 & Rini & $\begin{array}{l}\text { Keripik: } \\
\text { JOMBLO }\end{array}$ & $\begin{array}{l}\text { Bagaimana kita bisa membangun } \\
\text { networking yang baik untuk } \\
\text { mempertahankan bisnis atau usaha } \\
\text { kita.? }\end{array}$ \\
\hline
\end{tabular}




\begin{tabular}{|l|l|l|l|}
\hline 7 & Sandy & $\begin{array}{l}\text { Angkringan : } \\
\text { BETMEN }\end{array}$ & $\begin{array}{l}\text { Bagaimana kita bisa membangun list } \\
\text { building dan komunitas dari sudut } \\
\text { pandang marketing.? }\end{array}$ \\
\hline
\end{tabular}

Melihat beragamnya bentuk pertanyaan ataupun tanggapan yang diberikan oleh para fasilitator dan peserta, terlihat dengan jelas bahwa, semangat para pelaku UMKM dikomunitas Pemuda Gelam Jaya ternyata masih kearah optimism untuk memulai dan mempertahakan usaha yang dimiliki.

Kelemahan ataupun kekurangan yang ada pada peserta hampir semua mengutamakan atau mengarah pada aspek pembiayaan (keuangan), oleh karena itu, hasil dari pendampingan secara online ini akan disampaikan pula kepada pihak desa Gelam Jaya agar bisa membuat sebuah kebijakan untuk menggandeng dinas-dinas terkait agar bisa memaksimalkan pendapatan asli lingkungan (PAL) sehingga dapat membantu para pelaku usaha dalam bentuk kerjasama antara pelaku usaha dengan dinas terkait.

Tolak ukur keberhasilan ini didukung dengan adanya tanggapan dari pihak desa Gelam Jaya yang begitu sangat terbantu terhadap masukan-masukan informasi yang cukup beharga dalam kegiatan pengabdian masyarakat yang diarahkan khusus untuk komunitas pemuda desa Gelam Jaya, dimana pihak desa Gelam Jaya memberikan dokumen terkait rencana pengembangan jangka menengah desa (atau yang lebih dikenal sebagai RPJMDes) Desa Gelam Jaya, Kec. Pasar Kemis, Kabupaten Tangerang, dimana dalam dokumen ini memuat dokumen perencanaan strategis jangka menengah desa yang berjangka waktu 6 tahun dan ditetapkan dengan Peraturan Desa. Dan pada akhirnya harapan dari pihak Desa adalah, dapat memasukkan informasi penting terkait peningkatan Pendapatan Asli Lingkungan (PAL) khusus Desa Gelam Jeaya dengan menumbuhkembangkan dan mendorong peran serta masyarakat dalam pembangunan di desa (Solihin, Setiawan, Teknik, \& Pamulang Tangerang Selatan, 2020)

\section{KESIMPULAN}

Bahwa desa adalah desa adat atau yang disebut dengan nama lain, selanjutnya disebut desa, adalah kesatuan masyarakat hukum yang memiliki batas wilayah yang berwenang untuk mengatur dan mengurus urusan pemerintahan, kepentingan masyarakat setempat berdasarkan prakarsa masyarakat, hak asal usul dan atau hak tradisional yang diakui dan dihormati dalam Sistem Pemerintahan Negara Kesatuan Republik Indonesia, berdasarkan Undang-Undang Nomor 6 Tahun 2014 sebuah system pelayanan masyarakat setingkat Desa telah diberikan wewenang untuk mengatur rumah tangga desa, mengelola anggaran dan melaksanakan proses-proses pembangunan desa sejak dari proses perencanaan hingga proses pelestarian, dan dalam pelaksanaan pembangunan tersebut khusus dibidang pembinaan kemasyarakatan dan bidang oemberdayaan masyarakat maka memerlukan adanya sebuah informasi atau masukan yang harus diketahui oleh pihak desa dalam mengupayakan pembangunan di desa, sehingga perencanaan seluruh warga Desa Gelam Jaya, khususnya bagi komunitas pemuda desa gelam jaya bisa menjadi bagian dalam proses pembangunan masyarakat sehingga bisa mewujudkan masa depan desa yang lebih baik, khususnya dari sisi pelaku usaha (Jaya, 2019).

Kegiatan pengabdian kepada masyarakat yang dilakukan berkat kerjasama dari tim fasilitator dari dunia pendidikan kepada para pemuda yang bernaung dalam sebuah komunitas pemuda desa gelam jaya, diharapkan akan menjadi bibit baru dalam pendampingan dan pembentukan semangat serta strategi yang baik agar bisa meningkatkan taraf hidup mereka 
masing-masing khususnya bagi pembangunan masyarakat yang berada di desa gelam jaya (Sofianto, 2017).

Strategi AVP (Avaibility, Visibility, dan Promotion) mungkin bisa menjadi pemicu semangat para peserta khususnya para pemuda untuk tetap gigih mempertahankan jenis usaha atau bisnisnya disaat yang tidak mudah kita lewati seperti saat ini, bagaimana sebuah produk dapat bertahan didalam dunia pasar maka memerlukan adanya instrument avaibility, visibility dan tentu saja diselingi dengan promotion.Kesimpulan harus mengindikasi secara jelas hasil-hasil yang diperoleh, kelebihan dan kekurangannya, serta kemungkinan pengembangan selanjutnya.

\section{UCAPAN TERIMA KASIH}

Penulis mengucapkan terima kasih kepada Pengurus RT-RW 025 dan Pihak Desa Gelam Jaya yang telah memberi dukungan baik yang bersifat materi maupun non-materiil terhadap pengabdian ini.

\section{DAFTAR PUSTAKA}

Humas. (2020). Presiden: Jadikan Momentum Pandemi Sebagai Kebangkitan Baru Lakukan Lompatan Besa. Retrieved March 11, 2021, from https://setkab.go.id/ website: https://setkab.go.id/presiden-jadikan-momentum-pandemi-sebagai-kebangkitan-barulakukan-lompatan-besar/

Jaya, P. D. G. (2019). RPJMDES. Kab. Tangerang.

Pelaksanaan Kewajiban, P., Aribowo, I., \& Usman, F. (2018). SEMBADHA 2018 Seminar Hasil Pengabdian Kepada Masyarakat PERPAJAKAN BENDAHARA DESA GELAM JAYA KECAMATAN PASAR KEMIS KABUPATEN TANGERANG. In Prosiding Sembadha (Vol. 1). Retrieved from http://jurnal.stan.ac.id/index.php/sembadha/article/view/378

Roza, D., \& S, L. A. (2018). Peran Badan Permusyawaratan Desa di Dalam Pembangunan Desa dan Pengawasan Keuangan Desa. PADJADJARAN Jurnal IImu Hukum (Journal of Law), 4(3), 606-624. https://doi.org/10.22304/pjih.v4n3.a10

SEA Internet_Economy_Report_2019. (2019). Retrieved March 11, 2021, from https://www.blog.google/documents/47/SEA_Internet_Economy_Report_2019.pdf

Sofianto, A. (2017). Kontribusi Dana Desa terhadap Pembangunan dan Pemberdayaan Masyarakat di Kebumen dan Pekalongan. Matra Pembaruan, 1(1), 23-32. https://doi.org/10.21787/mp.1.1.2017.23-32

Solihin, L., Setiawan, A., Teknik, F., \& Pamulang Tangerang Selatan, U. (2020). ADMINISTRATION COMPETENCY IMPROVEMENT TRAINING USING OFFICE APPLICATIONS ON YOUTH ORGANIZATION RT05 RW08 GELAM JAYA-PASAR KEMIS-TANGERANG. In PROSIDING SENANTIAS: Seminar Nasional Hasil Penelitian dan Pengabdian kepada Masyarakat (Vol. 1). Retrieved from http://openjournal.unpam.ac.id/index.php/Senan/article/view/9052

Statistik, B. P. (2019). Indeks Pembangunan Manusia 2018. Retrieved March 2, 2021, from BPS website: https://www.bps.go.id/publication/2019/08/27/34432798c6ae95c6751bfbba/indekspembangunan-manusia-2018.html

Statistik, B. P. (2020). Indeks Pembangunan Manusia. Jakarta.

Tjiptono, F. (2015). Strategi Pemasaran (4th ed.). Yogyakarta: CV. Andi Offset.

Widiana, M. E. (2010). Dasar-Dasar Pemasaran (1st ed.). Bandung: Karya Putra Darwati 
Bandung. 